\title{
1. Introduction: the EU's quest for a more coherent Russia policy
}

It is always important that the EU speaks with a coherent voice to its partners

(Interview 46).

Russia is the epitome why it doesn't work

(Interview 11).

The two quotes above are at the heart of a paradox that inherently characterizes the foreign policy of the European Union (EU). On the one hand, there is widespread agreement that the EU should become a more coherent external actor. In the context of EU foreign policy-making, coherence-both between political actors and different external policies - is understood as a key element to increase the Union's international impact. On the other hand, the EU repeatedly fails to meet this aim. The effectiveness of its external approach is undermined by deep internal divisions between actors and across policy areas. In practice, the notion of the EU as an influential international actor frequently turns out to be wishful thinking rather than a reality. Relations with Russia are a prime example in this respect. The EU and its Member States have a major stake in the eastern neighbor, yet coherence of their external policies is frequently undermined by a fundamental conflict over interests and approach.

Calls for a stronger external role of the EU are rooted in the uniqueness of the project of European integration. Since the Treaty of Rome, it has preserved peace among its Member States on a formerly war-prone continent, contributed to economic growth and prosperity for its citizens, and created a shared body of European law. The list is non-exhaustive and could be extended with many more exceptional attributes: the EU is one of the largest economies in the world with a gigantic internal market and a common currency, it has a system of shared values, and it grants fundamental rights to every citizen. Despite the fact that it is not a state per se, it shapes the lives of more than 500 million people. Due to such achievements, the EU is widely regarded as a success story. The vast majority of policy-makers and observers are of the opinion that these internal achievements should be reflected in a stronger international role of the EU.

Since the early days of the EU as an international actor, its external performance has been subject to heated debates. Most practitioners and observers agree that the EU lacks international impact. Inter alia, it has been referred 
to as an "economic giant, a political dwarf, and a military worm" (Belgian Foreign Minister Mark Eyskens quoted in Whitney 1991) and was prominently criticized for "simply not punching its weight on the international stage" (European Commission President Jacques Santer quoted in Cameron 2009: 19; see also Diez Medrano 1999; Thomas 2012). A seminal scholarly contribution in the field identified a gap between the Union's external capabilities and expectations (Hill 1993). In order to increase the Union's external effectiveness, the past decades witnessed a plethora of policy initiatives and reforms that culminated in the creation of the European External Action Service (EEAS) and the post of the High Representative of the Union for Foreign Affairs and Security Policy (HR). Accordingly, the first HR Catherine Ashton interpreted her mandate as to help Europe "punch its weight" politically (EP 2009).

The limited external impact of the EU is generally associated with a lack of coherence between Member States, EU institutions, policies and instruments. The Council Conclusions of October 2000 identified "that reinforcing the coherence of the Union's external action and realising its policy objectives are priorities if the Union is to pull its full weight in international affairs" (Council of the EU 2000). Similar references to coherence are a recurrent theme in a multitude of documents and public statements of high-level speakers from the 1970s until today. They are evidence of a shared perception that coherence is the key towards more external effectiveness. It is striking that despite this centrality of the notion, coherence has never been officially defined. According to the working definition advanced in Chapter 2, coherence in this book is understood as the presence of synergies between external policies and objectives of the EU and its Member States.

The lack of external coherence is arguably most visible in the relations of the EU with Russia. There is a constant imbalance between expectations for impact and actual external achievements. On the one hand, as the EU's largest neighbor with close trade ties, a shared history and geo-strategic importance, Russia is naturally at the center of attention. Given its relevance, Member States share a broad consensus that a combined European effort vis-à-vis Russia could be beneficial. This view is manifested in frequent calls for a "Europe speaking with one voice". On the other hand, Brussels has revealed more difficulties in coordinating different policies and interests into a coherent external approach towards Moscow compared to any other partner. This becomes most evident in the area of energy. Due to their high dependence on Russian energy supplies, some EU members regard their priorities in the area as a matter of national security and sovereignty which dominates all other external interests. For instance, Member States have resisted initiatives to pool energy purchases; they have kept secret from each other their gas prices which they had negotiated with Moscow; they have competed for the establishment 
of gas pipeline hubs; and they engaged in bilateral pipeline projects with Russia that are rival to other Member States' interests. Discrepancies exist also in more value-based policy areas like human rights. In the past, EU members have repeatedly revealed disagreement about the external instruments to promote and enforce the EU's human rights policy in Russia. Responses in specific human rights cases therefore often reflect no more than the lowest common denominator, an outcome that does not match the EU's ambition to be a vigorous defender of human rights in the world.

Such examples illustrate the difficulty in finding consensus among 28 Member States and in aggregating different foreign policy objectives into a unified Russia policy. In this context, the former Commissioner for External Trade, Peter Mandelson, pointed out that "the incoherence of European policy towards Russia [...] has been frankly alarming. No other country reveals our differences as does Russia" (European Commission 2007). In the same vein, a scholarly analysis has emphasized that the "relationship with Russia has arguably been the most divisive factor in EU external relations policy" (Schmidt-Felzmann 2008: 170).

The difficulty of the EU to agree on a common foreign policy towards Russia is sometimes framed as a collective action problem (cf. Olson 1965): 28 Member States with diverse interests are unlikely to find agreement, particularly on issues where high interests are at stake. However, such an argument is too simplistic as it disregards the fact that the EU has always been a diverse polity where consensus is required for certain outcomes (cf. Scharpf 2006). In EU external policy-making, this requirement is reflected in three fundamental characteristics that commonly aim at overcoming national differences. First, EU foreign policy is extensively institutionalized. Successive reforms have improved the coordination between relevant actors, eased information-sharing, simplified decision-making and encouraged consensus-finding. Second, the area rests on a catalogue of formally stated objectives. It includes references to broad norms and values as well as to more explicit external goals. This combination provides political and practical guidance in both the long-term and in specific policy episodes. Finally, the development of EU external relations enjoys popular political backing. European leaders have repeatedly expressed political will to act more coherently and speak with one voice. This attitude is also enshrined in the Treaty on European Union which stipulates that Member States ought to support common foreign policies "in a spirit of loyalty and mutual solidarity" (Art. 24 para. 3 TEU).

Over time, these three features have contributed to a remarkable maturation of EU foreign policy. Contrary to how it is sometimes depicted, the way in which the EU formulates and decides upon its external policies is far from being a random, ad hoc exercise. Extensive institutionalization, a catalogue of formally stated objectives and repeatedly articulated political will—should 
these attributes of EU foreign policy not be sufficient to facilitate and ensure external coherence?

With regard to the relations of the EU with Russia, the answer to this question is a clear "no". Illustrated more prominently than with any other country, Brussels' enormous efforts to become a more coherent external actor do not often materialize. The central research question of this book therefore reads:

Why is the external policy of the EU towards Russia lacking coherence, despite extensive institutionalization, a catalogue of formally stated objectives and repeatedly articulated political will?

The aim of this book is to unfold the contradiction between the external ambitions and the external achievements of the EU. It is striking that the term "coherence" has never been officially defined despite its crucial role in debates around EU foreign policy. The central research question thus needs to be read in conjunction with a number of sub-questions: What is the role of coherence in EU foreign policy-making? How does coherence impact on the effectiveness of EU foreign policy? What are the key features to enhance external coherence? And which factors constrain such a development?

This book uses the vast empirical laboratory of EU-Russia relations and particularly the specific areas of energy and human rights policy to answer these questions. The main argument is twofold. First, external coherence is not a marginal normative claim but a self-defined objective that is practically incorporated in the EU foreign policy context. It reflects a broad consensus that the degree of coherence is positively related to the effectiveness of its foreign policies. Chapter 3 shows that the quest for more coherence has become a guiding principle of EU foreign policy. The external unity of the Union is constantly challenged by multiple actors, decentralized competences, and policy areas that are subject to different decision-making procedures. Coherence is interpreted as a practical answer to overcome this functional fragmentation of the Union's external policies. There is no clear-cut dichotomy between coherence and incoherence, but the quest for coherence embodies the idea to achieve more external coherence. Consequently, the empirical chapters deal with the identification of different factors that impact positively or negatively on the degree of external coherence.

Second, the focus on coherence yields new perspectives on the topic of EU foreign policy. Chapter 2 advances a dual analytical approach that informs a number of novel research propositions to investigate facilitators and obstacles of coherence. It rests on a distinction between the policy setting and the policy content. The policy setting stands synonymously for an institutionalist research agenda. Employed in Chapter 4, it explores the conduciveness of the EU's institutional structure to more external coherence. It is argued that 
the policy setting can account for much of the variation in policy outcomes. A more comprehensive image of the EU as an international actor is, though, provided by an additional focus on the policy content. This approach is novel in that rather than focusing on institutional structures, it highlights the impact of the EU's external objectives on coherence. External objectives are analytically grasped through the application of Arnold Wolfers' dichotomy of milieu and possession goals to the specific context of the EU. It claims that any external action is rooted in two types of goals: whereas milieu goals are concerned with the external environment, possession goals seek to secure something to which value for domestic use is attributed (Wolfers 1962). Chapters 5 and 6 find that the EU is a milieu shaper towards Russia: it seeks to promote its norms and values and thereby shapes the external environment. A lack of external coherence, it is argued, results from a constant tension between milieu and possession goals. In cases where these tensions can either be avoided or resolved, the EU's external policies are likely to be coherent. These findings inform a number of recommendations that can help to formulate more coherent external policies in the future.

The findings of this book have both practical and theoretical implications. On the one hand, it offers an extended understanding to the difficulties the EU faces in foreign policy-making. Scholarship in the field is traditionally dominated by contributions drawing on institutionalist research agendas that explain policy outcomes with reference to the policy setting (Aggestam et al. 2008; cf. Aspinwall and Schneider 2000; Duke 2011; Edwards 2013; Smith 2013; Vanhoonacker and Pomorska 2013). This book acknowledges the wide explanatory potential of these approaches. Nevertheless, the focus on the policy content and the advanced dichotomy of milieu and possession goals bear additional insights. Chapter 6 and the conclusion (Chapter 7) advance practical guidelines indicating how milieu and possession goals can be coordinated to result in external coherence.

On the other hand, the finding that the EU is a milieu shaper towards Russia sets a new theoretical focus. Compared to power-based explanations of previous research that labeled the EU as a "civilian" and "economic power" (Bull 1982; Duchêne 1973), a "normative power" (Manners 2002), a "normal power" (Pacheco Pardo 2012), a "market power" (Damro 2012), a "regulatory power" (Goldthau and Sitter 2015), a "realist power" (Zimmermann 2007), a "military power" (Wagner 2006), a "small power" (Toje 2008) and even a "superpower" (McCormick 2007; Moravcsik 2002; Whitman 1998), the image of the EU as an external milieu shaper is theoretically more encompassing. As suggested by the case studies in this book, the dominance of milieu goals in the EU's external relations towards Russia is prevalent in policy areas as diverse as energy and human rights policy. This conclusion informs the development of a theoretical perspective that explains the external identity and "nature of 
the beast" (Risse-Kappen 1996) in terms of its objectives rather than sources of power.

\section{OUTLINE OF THE BOOK}

The book is structured along five main chapters. Chapter 2 develops the analytical framework for research on external coherence. It reviews theories and literature from the scholarly fields of International Relations (IR) and European Studies and assesses their potential to explain varying outcomes of EU external policies. A special focus in explaining the external performance of the EU is placed on coherence: the concept is defined, structured and operationalized. On this basis, the chapter proposes the above-mentioned dual analytical approach to investigate the coherence of EU foreign policy. A distinction is drawn between the policy setting and the policy content, and Arnold Wolfers' conceptualization of milieu and possession goals is introduced to investigate the latter. On basis of this analytical work, a set of research propositions on external coherence are formulated that inform the following four empirical chapters.

The third chapter demonstrates the practical relevance of the concept of coherence. Based on interviews, it reviews the role and the meaning of coherence in the context of EU external relations. The interview responses confirm the significance of the theoretically derived conceptual characteristics. Coherence between actors and policies is a recurrent theme in debates in Brussels. Moreover, it is shown that coherence has become a guiding principle in EU external relations that is inherently linked to the problems arising from a fragmented institutional structure.

Chapter 4 addresses the first part of the dual analytical approach: it investigates the policy setting of the EU and its impact on external coherence towards Russia. A central element to increase coherence is the ability to coordinate the interests of different actors and between different policy areas. On the one hand, this is reflected in the formal institutional structure of external policy-making. The chapter reviews procedures and reforms in the European Council, the Council of the European Union, the European Commission, the HR and the EEAS, and their impact on external coherence. On the other hand, the coordination of interests is facilitated by a number of informal practices that have developed in the EU's institutional structure. Socialization processes between actors, the development of common values and objectives, like-minded groups, the practice of uploading, and guidance through common agenda-setting and agreement on principles have become facilitators of coordination that advanced alongside formal institutional design. Conversely, there are also certain elements of the policy setting that undermine the external coherence of the EU, including missing competences at the supranational 
level, a fragmented institutional framework, turf wars between institutional actors, a lack of strategic objectives and administrative overload.

Chapters 5 and 6 are informed by the second part of the dual analytical approach employed in this book: the focus of the analysis rests on the policy content. Chapter 5 investigates the relations of the EU with Russia from a macro-level perspective. It assesses the external role of the EU in rebuilding and consolidating the relationship since the end of the Cold War. It provides various examples of how the EU's activities in the areas of human rights and energy policy seek to shape the relationship with Russia and the Eastern neighborhood. The institutionalization of the partnership at the political and expert level, combined with frequent references to norms and values, has effectively become an instrument of external governance. While these elements depict the EU as a relatively coherent external actor, this picture is repeatedly undermined by a number of external and internal challenges. Russia increasingly challenges common norms and values - most recently illustrated by the Ukraine crisis. At the same time, Brussels' responses are often constrained by its lack of identity as an international actor.

Chapter 6 assesses the external coherence of the EU towards Russia in specific policy areas and episodes. It is shown that problems in achieving external coherence appear when tensions between milieu and possession goals cannot be resolved. Analyses of the EU's external human rights and energy policy suggest that coherence is dependent on mechanisms that avoid a conflict between different foreign policy objectives: where the EU engages solely in milieu-shaping activities without challenging possession goals, external policies are relatively coherent. Moreover, Chapter 6 presents three distinct case studies from the areas of energy and human rights policy in which the interaction of milieu and possession goals caused different outcomes. The Polish-Russian gas negotiations of 2010 successfully avoided a conflict and became an example of a successful coordination of objectives that resulted in external coherence. In EU responses to human rights violations in Russia, tension between different objectives could only partly be resolved. Often, the EU's external action is therefore characterized by a lack of coherence. Finally, the case of the European Council in Lahti exemplifies a failed attempt to coordinate different external objectives, resulting in an ongoing lack of external coherence. Based on insights from the policy areas and the cases, the chapter concludes with an overview displaying different modes of coordinating objectives and the likelihood for policy coherence.

Finally, the conclusion in Chapter 7 reviews the main findings of the four empirical chapters, identifies answers to the central research question, and assesses their implications for policy-making and future research. 


\section{A NOTE ON THE RUSSIA CASE AND METHODS}

This book investigates challenges of external coherence encountered by the EU in its relations with Russia. While problems with external coherence are a relatively common phenomenon permeating EU external relations with many third countries, the choice for a special focus on Russia is rooted in several arguments. The EU and its Member States have particularly close historical, cultural, economic and political ties with the eastern neighbor. Most of them have high stakes in Russia, albeit their individual interests can differ considerably. Russia has also a special status due to its importance as the main supplier of energy commodities to the EU, its geo-strategic importance, and its relevance for security in the common neighborhood. Given this background, calls to speak with one voice and act coherently have become particularly loud vis-à-vis Russia. It is for similar reasons that Brussels has attempted to rebuild and consolidate its relationship with Moscow since the end of the Cold War. This relatively recent and still ongoing development offers a rich and new laboratory for empirical research, unrivaled by case studies investigating EU relations with other partners. Finally, with no other external partner is the relationship characterized to the same extent by a coherence paradox: despite a historically unparalleled deepening of EU-Russia relations, the return of tensions and the lack of a coherent Russia policy have become the central characteristics of Brussels' engagement with Moscow.

The emphasis of this book lies on the time after the fall of the Iron Curtain. This period coincides with the Russian transition to a democracy and market economy and a deepening of relations with the EU in all aspects. A special focus in the analysis is placed on the areas of energy and human rights for four reasons. First, within the EU, both energy and human rights policy play a specific role. Human rights are foundational to the EU's values system and repeatedly mentioned to be at the basis of EU external action. Their importance is highlighted by the fact that they constantly feed into other policy areassometimes referred to as "mainstreaming" human rights - as well as by the EU's role in establishing human rights dialogues with third countries around the world. Energy, on the other hand, has been at the core of the European integration project with the European Coal and Steel Community, and once more arrived at the top of the political agenda in 2015 with the launch of the Energy Union. Nowadays, its importance is rooted in the relative shortage of fossil fuel resources on EU territory and the dependence on external suppliers. Second, both fields lie at the heart of EU-Russia relations and provide insights in the roles that interests, norms and values play in the partnership. An investigation of the policy areas offers both a better understanding of mutual interdependencies as well as causes for tensions. Third, both policy areas are 
subject to deep and ongoing institutionalization between the EU and Russia. The plethora of established bilateral forums at political and expert levels is a rich laboratory for scholarly research on the EU's quest for more coherence. Moreover, longitudinal institutional analysis provides valuable insights on the development of relations and the EU's role as an external actor. Finally, regarding the institutional processes in the EU, external energy and human rights policy are subject to different decision-making procedures. While external human rights policy largely falls under the EU's Common Foreign and Security Policy (CFSP), energy policy is an area in which the EU and Member States have shared competences. The resulting procedural differences provide further insights in the challenges the EU faces to act externally coherently.

The data employed in this book was collected from primary and secondary sources. Primary sources include interviews, publicly accessible documents from the EU and Member States, undisclosed EU documents received from interviewees, as well as published speeches from politicians and policy-makers. Most data for the book was collected through 55 semi-structured interviews with officials from EU institutions and services, Member States and other organizations conducted in the period between 2011 and 2019. Another primary source frequently utilized was European Council Conclusions. Secondary sources mainly comprise academic and media publications. The latter were retrieved from official websites of official EU or national institutions, as well as non-governmental organizations and the news agency "Agence Europe". In addition, statistical data from Eurostat and other official sources was utilized.

\section{REFERENCES}

Aggestam, L., F. Anesi, G. Edwards, C. Hill and D. Rijks (2008), Institutional Competences in the EU External Action: Actors and Boundaries in CFSP and ESDP, Stockholm: Swedish Institute for European Policy Studies.

Aspinwall, M.D. and G. Schneider (2000), "Same menu, separate tables: the institutionalist turn in political science and the study of European integration", European Journal of Political Research, 38 (1), 1-36.

Bull, H. (1982), "Civilian power Europe: a contradiction in terms?", Journal of Common Market Studies, 21 (2), 149-70.

Cameron, F. (2009), "The politics of EU-Russia energy relations", The EU-Russia Center Review, EU-Russia Energy Relations (9, June), 20-29.

Council of the EU (2000), 2294th Council Meeting (General Affairs), Conseil/00/364, Luxembourg, 9 October, accessed at http://europa.eu/rapid/press-release_PRES-00 -364 en.htm?locale=en.

Damro, C. (2012), "Market power Europe”, Journal of European Public Policy, 19 (5), 682-99.

Diez Medrano, J. (1999), "The European Union: economic giant, political dwarf”, in T.V. Paul and J.A. Hall (eds), International Order and the Future of World Politics, Cambridge: Cambridge University Press, pp. 155-77. 
Duchêne, F. (1973), "The European Community and the uncertainties of interdependence", in M. Kohnstamm and W. Hager (eds), A Nation Writ Large? Foreign-Policy Problems before the European Community, London: Macmillan, pp. 1-21.

Duke, S. (2011), "Consistency, coherence and European Union external action: the path to Lisbon and beyond", in P. Koutrakos (ed.), European Foreign Policy: Legal and Political Perspectives, Cheltenham, UK and Northampton, MA, USA: Edward Elgar Publishing, pp. 15-54.

Edwards, G. (2013), “The EU's foreign policy and the search for effect”, International Relations, 27 (3), 276-91.

EP (2009), "Catherine Ashton: EU should do more to 'punch its weight' politically", Press Releases REF.: 20091202IPR65813, European Parliament, 2 December, accessed at http://www.europarl.europa.eu/sides/getDoc.do?type=IM-PRESS\& reference $=20091202$ IPR $65813 \&$ format $=$ XML\&language $=E N$.

European Commission (2007), "The EU and Russia: our joint political challenge", speech by EU Trade Commissioner Peter Mandelson, SPEECH/07/242, Bologna, 20 April.

Goldthau, A. and N. Sitter (2015), A Liberal Actor in a Realist World: The European Union Regulatory State and the Global Political Economy of Energy, Oxford: Oxford University Press.

Hill, C. (1993), "The capability-expectations gap, or conceptualizing Europe's international role", Journal of Common Market Studies, 31 (3), 305-28.

Manners, I. (2002), "Normative power Europe: a contradiction in terms?", Journal of Common Market Studies, 40 (2), 235-58.

McCormick, J. (2007), The European Superpower, Basingstoke: Palgrave Macmillan.

Moravcsik, A. (2002), "The quiet superpower", Newsweek - International Edition, 17 June.

Olson, M. (1965), The Logic of Collective Action: Public Goods and the Theory of Groups, Cambridge, MA, USA and London, UK: Harvard University Press.

Pacheco Pardo, R. (2012), "Normal power Europe: non-proliferation and the normalization of EU's foreign policy", European Integration, 34 (1), 1-18.

Risse-Kappen, T. (1996), "Exploring the nature of the beast: international relations theory and comparative policy analysis meet the European Union", Journal of Common Market Studies, 34 (1), 53-80.

Scharpf, F.W. (2006), "The joint-decision trap revisited", Journal of Common Market Studies, 44 (4), 845-64.

Schmidt-Felzmann, A. (2008), “All for one? EU member states and the Union's common policy towards the Russian Federation", Journal of Contemporary European Studies, 16 (2), 169-87.

Smith, M.E. (2013), "The European external action service and the securitydevelopment nexus: organizing for effectiveness or incoherence?", Journal of European Public Policy, 20 (9), 1299-315.

Thomas, D.C. (2012), "Still punching below its weight? Coherence and effectiveness in European Union foreign policy", Journal of Common Market Studies, 50 (3), 457-74.

Toje, A. (2008), “The European Union as a small power, or conceptualizing Europe's strategic actorness", Journal of European Integration, 30 (2), 199-215.

Vanhoonacker, S. and K. Pomorska (2013), "The European external action service and agenda-setting in European foreign policy", Journal of European Public Policy, 20 (9), 1316-31. 
Wagner, W. (2006), "The democratic control of military power Europe", Journal of European Public Policy, 13 (2), 200-216.

Whitman, R.G. (1998), From Civilian Power to Superpower? The International Identity of the European Union, London: Macmillan.

Whitney, C.R. (1991), "War in the Gulf: Europe; gulf fighting shatters Europeans", New York Times, 25 January.

Wolfers, A. (1962), Discord and Collaboration: Essays on International Politics, Baltimore, MD: Johns Hopkins University Press.

Zimmermann, H. (2007), "Realist power Europe? The EU in the negotiations about China's and Russia's WTO accession”, Journal of Common Market Studies, 45 (4), 813-32. 